\title{
Mourad Aouati \\ PARAMETRIC IDENTIFICATION IN THE PROBLEM OF DETERMINING THE QUALITY OF DUSULFUSATION AND DEPOSPHORATION PROCESSES OF Fe-C ALLOY
}

\begin{abstract}
На основі реалізації параметричного методу розпізнавання образів встановлена можливість побудови класифікуючого правила, що дозволяе з високою точністю провести ідентифікацію ділянки дуплекс-прочесу плавки «вагранка - електродугова піч», що має більш низький показник параметричної надійності. Це дозволяє його рекомендувати для систем підтримки прийняття рішень з управління процесами десульфуращії і дефосфорачії в дуплекс-прочесі плавки.
\end{abstract}

ключові слова: параметричні методи розпізнавання образів, класифікуюче правило, десульфуращія, дефосфорачія.

\section{Introduction}

Considering metallurgical processes as objects of research, it should be noted that by the nature of the description they can be referred to the category of chemical-technological processes. The fact that such processes realized in industrial furnaces are described by heterogeneous oxidation-reduction reactions occurring in the «melt-slag-atmosphere» medium speaks in favor of this. The nature of these processes affects the functioning of melting technological systems and predetermines the choice of control actions. Given the multidimensionality of these objects and their inertia, the main areas of research in this area are focused on the creation of information systems for decision support [1,2] and also focused on the development of mathematical support for such information systems [3, 4]. At the same time, the processes of desulfurization and dephosphorization of the melted alloy are the priority for adequate description and subsequent information support of control systems. The discrepancy between the quality of control of these processes leads to the formation of the red-short of the alloy due to overestimated concentrations of sulfur in it and cold brittleness due to overestimated concentrations of phosphorus in it. According to the system description of the desulfurization and dephosphorization processes presented in [5], the main directions of the realization of these processes can be singled out. Thus, sulfur forms sulphides with some metals, and they can have both unlimited solubility in iron and not dissolve in it practically at all. Sulfur forms sulfide FeS with iron, which has unrestricted solubility in iron. The purpose of desulfurization is the removal of sulfur from the melt into the slag. This is achieved through the transition of sulfur from the active form (soluble in the melt) to the passive (slightly- and insoluble). With an excess of calcium oxide and high temperature, the following reaction occurs with iron sulfide: $\mathrm{FeS}+\mathrm{CaO}=\mathrm{CaS}+\mathrm{FeO}$.

Calcium sulphide is completely insoluble in the metal and is released completely into the slag. When steel melting, this reaction can't be completely, because in slag there is a significant amount of ferrous oxide, which reacts with calcium sulphide, as soon as its content in the slag increases. Therefore, with a high content of ferrous oxide in the slag, there can be only a little calcium sulphide in it. The content of this compound in the slag increases as the basicity of the slag increases. Carbon, silicon and aluminum greatly reduce the solubility of sulfur in iron, thus increasing the sulfur activity to desulfurization. Desulphurization of cast iron can also be carried out with manganese, which also increases the sulfur activity to desulfurization $(\mathrm{FeS} \rightarrow \mathrm{MnS})$. Manganese sulphide passes into slag. The development of this reaction in liquid steel is limited due to the fact that the activity of sulfur in steel is much lower than in cast iron. Therefore, the use of manganese for the desulphurization process has become effective only in high-manganese steels.

A method for increasing the efficiency of steel desulphurization process is diffusion deoxidation when treating white slags with coke and ferrosilicon powders or by addition of fluorite into the melt of fluorspar $\left(\mathrm{CaF}_{2}\right)$ [5].

Phosphorus in the steel is in the form of an iron phosphide, the oxidation of which passes through the reaction: $2 \mathrm{Fe}_{3} \mathrm{P}+5 \mathrm{FeO}=\mathrm{P}_{2} \mathrm{O}_{5}+11 \mathrm{Fe}$. The compound $\mathrm{P}_{2} \mathrm{O}_{5}$ formed as a result of this reaction is insoluble in steel and passes into a slag. If in the slag there is in excess free calcium oxide, then the reaction proceeds: $\mathrm{P}_{2} \mathrm{O}_{5}+4 \mathrm{CaO}=\mathrm{Ca}_{4} \mathrm{P}_{2} \mathrm{O}_{9}$. The compound $\mathrm{Ca}_{4} \mathrm{P}_{2} \mathrm{O}_{9}$ formed as a result of this reaction is very strong and is removed by slag runoff. If there is a lot of silicon oxide in the slag, then ferrous oxide and calcium oxide combine with it as a stronger acidic oxide, and phosphorus pentoxide remains in the slag in the free state.

At high temperature, phosphorus pentoxide $\mathrm{P}_{2} \mathrm{O}_{5}$ is reduced by carbon dissolved in the steel, and the resulting free phosphorus again passes into the steel: $\mathrm{P}_{2} \mathrm{O}_{5}+5 \mathrm{C}=2 \mathrm{P}+5 \mathrm{CO}$ [5].

Thus, knowing the principles of oxidation-reduction reactions, it is possible to develop algorithms for desulphurization and dephosphorization control. Such algorithms should be based on the system of classifying rules «if, ..., then» 
and allow their use in decision support systems for choosing the control of melting processes. If the melting is carried out not in one furnace, but in two - a duplex process another urgent problem arises. It is related to the following circumstance. If in the final product - alloy - the concentration of sulfur and/or phosphorus is higher than the allowable limit, it is necessary to determine which of the series-connected units of the technological system is «responsible» for the resulting reject of the final product.

\section{The object of research and its technological audit}

The object of research is the duplex process of cast iron melting «cupola - electric arc furnace», realized in the foundry shop of an engineering enterprise. In a cupola - electric arc furnace, operating on the countercurrent principle, the solid charge, charged from above, is melted by the gases released from the combustion of solid fuels coke, or gaseous fuels. Molten cast iron flows through the tap hole in the receiver, seeping through the coke. If its quality is poor that is determined, first of all, by the presence of sulfur, the melt is intensely saturated with sulfur. The presence of a poor-quality charge with an increased content of phosphorus and the practical complexity of its removal directly in the process of melting in a cupola leads to the fact that the melt has a high content of sulfur and phosphorus, including those exceeding the permissible levels.

The second unit, the electric arc furnace, allows carry out desulfurization and dephosphorization processes, bringing he sulfur and phosphorus content to the specified limits. The purpose of the technological audit is to study the quality of the desulphurization and dephosphorization processes in the actual conditions of the workshop. This, in the forecast, makes it possible to build classifying rules allowing to identify a part of the technological process on which reject for the increased content of sulfur and/or phosphorus in the finished alloy are generated.

The functional automation schemes of both units correspond to typical ones [6] and are shown in Fig. 1, 2.

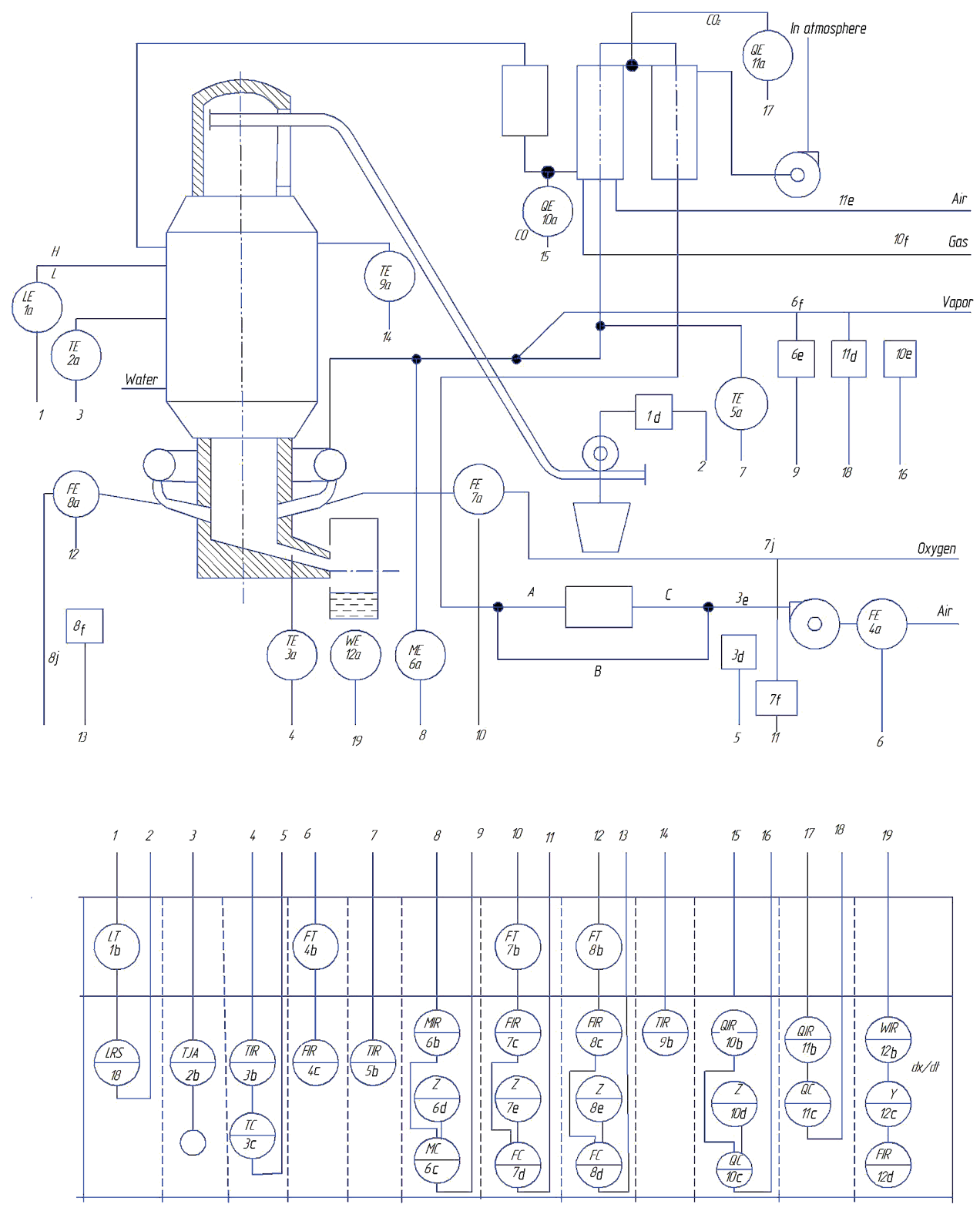

Fig. 1. Functional scheme of automation of cupola melting process 

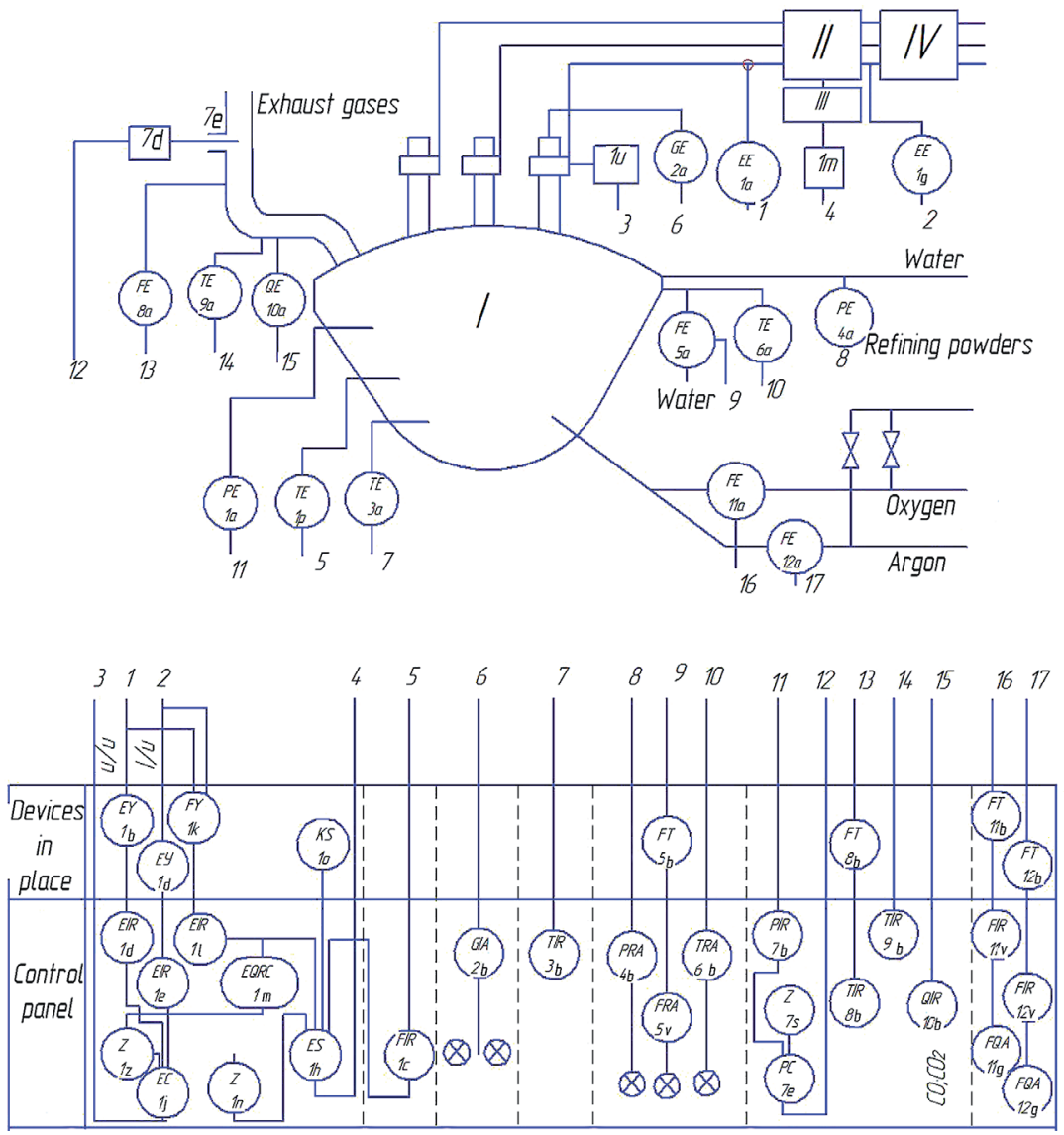

Fig. 2. Functional scheme of automation of electric arc melting process

Table 1 shows the results of a chemical analysis of the sulfur $(S)$ and phosphorus $(P)$ content in the melt produced in the cupola and electric arc furnaces during the melting. The readings are taken in the series melting process.

A visual assessment of the experimental data shows that cast iron melted in an electric arc furnace has lower concentrations of sulfur and phosphorus. This fact does not contradict the well-known opinion that cast iron of cupola melting has increased contents of sulfur and phosphorus. The reason for this is the saturation of these elements with the melt during percolation through a coke.

Table 1

The results of the chemical analysis of sulfur (5) and phosphorus $(P)$ content in the melt obtained in the cupola and electric arc furnaces

\begin{tabular}{|c|c|c|c|c|c|c|c|c|c|}
\hline \multirow{3}{*}{$\begin{array}{c}\text { № } \\
\text { of melting }\end{array}$} & \multicolumn{2}{|c|}{ Melting in cupola } & \multicolumn{2}{|c|}{ Melting in electric arc furnace } & \multirow{3}{*}{$\begin{array}{c}\text { № } \\
\text { of melting }\end{array}$} & \multicolumn{2}{|c|}{ Melting in cupola } & \multicolumn{2}{|c|}{ Melting in electric arc furnace } \\
\hline & $5, \%$ & $P, \%$ & $5, \%$ & $P, \%$ & & $5, \%$ & $P, \%$ & $5, \%$ & $P, \%$ \\
\hline & $x 1$ & $x 2$ & $x 1$ & $x 2$ & & $x 1$ & $x 2$ & $x 1$ & $x 2$ \\
\hline 1 & 0.093 & 0.08 & 0.094 & 0.077 & 19 & 0.106 & 0.065 & 0.061 & 0.084 \\
\hline 2 & 0.093 & 0.083 & 0.077 & 0.085 & 20 & 0.117 & 0.069 & 0.059 & 0.088 \\
\hline 3 & 0.12 & 0.076 & 0.076 & 0.073 & 21 & 0.108 & 0.07 & 0.053 & 0.09 \\
\hline 4 & 0.094 & 0.077 & 0.084 & 0.078 & 22 & 0.106 & 0.064 & 0.083 & 0.075 \\
\hline 5 & 0.13 & 0.073 & 0.075 & 0.093 & 23 & 0.128 & 0.091 & 0.068 & 0.072 \\
\hline 6 & 0.077 & 0.083 & 0.06 & 0.076 & 24 & 0.111 & 0.09 & 0.062 & 0.087 \\
\hline 7 & 0.095 & 0.094 & 0.064 & 0.07 & 25 & 0.117 & 0.086 & 0.068 & 0.08 \\
\hline 8 & 0.099 & 0.089 & 0.062 & 0.084 & 26 & 0.114 & 0.09 & 0.07 & 0.071 \\
\hline 9 & 0.099 & 0.087 & 0.057 & 0.069 & 27 & 0.113 & 0.08 & 0.068 & 0.096 \\
\hline 10 & 0.093 & 0.064 & 0.071 & 0.079 & 28 & 0.112 & 0.078 & 0.07 & 0.09 \\
\hline 11 & 0.096 & 0.064 & 0.07 & 0.082 & 29 & 0.093 & 0.078 & 0.087 & 0.072 \\
\hline 12 & 0.11 & 0.064 & 0.078 & 0.085 & 30 & 0.077 & 0.086 & 0.086 & 0.078 \\
\hline 13 & 0.096 & 0.062 & 0.076 & 0.086 & 31 & 0.101 & 0.075 & 0.08 & 0.089 \\
\hline 14 & 0.141 & 0.075 & 0.065 & 0.085 & 32 & 0.104 & 0.078 & 0.084 & 0.112 \\
\hline 15 & 0.184 & 0.078 & 0.066 & 0.084 & 33 & 0.116 & 0.07 & 0.089 & 0.09 \\
\hline 16 & 0.117 & 0.101 & 0.084 & 0.085 & 34 & 0.111 & 0.08 & 0.092 & 0.085 \\
\hline 17 & 0.148 & 0.091 & 0.083 & 0.083 & 35 & 0.114 & 0.08 & 0.071 & 0.093 \\
\hline 18 & 0.172 & 0.065 & 0.053 & 0.081 & & & & & \\
\hline
\end{tabular}




\section{The aim and objectives of research}

The aim of research is to build a classifying rule that allows to identify the aggregate of the technological system, the process in which led to a deviation in the content of sulfur and phosphorus.

To achieve the aim, the following tasks are set.

1. To carry out statistical processing of the experimental data and to choose the pattern recognition method on its basis.

2. To estimate the accuracy of the implementation of the chosen algorithm for building the classifying rule.

\section{Research of existing solutions of the problem}

The results of effective application of Bayesian statistics for solving applied problems of quality control in chemical-technological and metallurgical processes, as well as in materials science [7-10] are known. The aim of this approach is:

- determination of a section of the technological chain on which the parametric failure of the technological system is formed [7];

- identification of the alloy from the point of view

of its belonging to a certain brand [8, 9];

- determination of the location of defects in the macrostructure of materials [10].

An obvious disadvantage of these works is the lack of supporting justifications for the admissible accuracy of resulting classifying rules.

Modern approaches to improving the accuracy of classification, some authors associate with the use of neural networks [11-13], with emphasis on the quality of neural network training. Thus, it is proposed in [12] to use expert solutions for the neural network pattern recognition system. On their basis, based on the statistical data of observations, training samples are built. The result of applying the algorithm proposed by the authors is an increase in the relative share of correct expert estimates by an average of $20 \%$ and a decrease in the relative fraction of false ones by $50 \%$. This work, however, has the disadvantage that it does not present limitations on the use of the proposed method.

In these works, it is also noted that when creating universal systems for pattern recognition, it is impossible to control only one of the training models. And this is especially evident when trying to build universal systems for a wide range of applications.

In [11-13] another common disadvantage can be noted they do not take into account situations when the components of image vectors are not measurable with a sufficient accuracy degree. The uncertainty in the estimation of the parameters of the image vectors leads to the need for their indistinct description, the methods of which are described, for example, in [14, 15]. All described results are of interest in the theoretical plane and can be used to solve practical problems. However, sometimes it is possible to effectively use classical parametric methods for development of decision support systems in the industry.

\section{Methods of research}

The parametric methods of pattern recognition are chosen as the main method of research [16, 17]. Their task is on the basis of Bayes theorem about the conditional probability of belonging of the $j$-th object to the class $A$ and $B$ :

$$
\begin{aligned}
& P\left(A \mid x^{j}\right)=\frac{P(A) p_{A}\left(x^{j}\right)}{P(A) p_{A}\left(x^{j}\right)+P(B) p_{B}\left(x^{j}\right)}, \\
& P\left(B \mid x^{j}\right)=\frac{P(B) p_{B}\left(x^{j}\right)}{P(A) p_{A}\left(x^{j}\right)+P(B) p_{B}\left(x^{j}\right)},
\end{aligned}
$$

to build a classifying rule that allows to belong an object to one of the classes. In this case, if the mathematical expectations of the vector $X$ for classes $A$ and $B$ are denoted by $m_{A}$ and $m_{B}$, respectively, and assume that the covariance distribution matrix of the vector $X$ for the classes $A$ and $B$ are approximately equal, the probability density $p_{A}(X)$ and $p_{B}(X)$ as:

$$
\begin{aligned}
& p_{A}(X)=k e^{\left(-\frac{1}{2}\left(x-m^{A}\right)^{\prime} \operatorname{cov}^{-1}(x)\left(x-m^{A}\right)\right)}, \\
& p_{B}(X)=k e^{\left(-\frac{1}{2}\left(x-m^{B}\right)^{\prime} \operatorname{cov}^{-1}(x)\left(x-m^{B}\right)\right)},
\end{aligned}
$$

where $k$ is a constant multiplier.

In analytical descriptions (1) and $(2), \operatorname{cov}(X)$ is the covariance matrix $P(A), P(B)$ are the a priori probabilities of the classes, $p_{A}(X)$ and $p_{B}(X)$ are the probability distribution densities in the form:

$$
\begin{aligned}
& p_{A}(X)=d \exp \left(-\frac{1}{2}\left(x-m_{A}\right)^{T} \operatorname{cov}^{-1}(x)\left(x-m_{A}\right)\right), \\
& p_{B}(X)=d \exp \left(-\frac{1}{2}\left(x-m_{B}\right)^{T} \operatorname{cov}^{-1}(x)\left(x-m_{B}\right)\right),
\end{aligned}
$$

where $d$ is a constant factor,

$$
\operatorname{cov}(x)=\frac{1}{N} X^{T} X-m^{T} m
$$

is covariance matrix, $\operatorname{cov}^{-1}(x)$ is the inverse of the covariance matrix.

In this case, the object $x^{j}$ can be belonged to the class to which the greater conditional probability corresponds:

$$
\begin{aligned}
& x^{j} \in A \text { if } P\left(A \mid x^{j}\right) \geq P\left(B \mid x^{j}\right), \\
& x^{j} \in B \text { if } P\left(A \mid x^{j}\right)<P\left(B \mid x^{j}\right) .
\end{aligned}
$$

The classifying rule using the likelihood ratio $l\left(x^{j}\right)$ can be represented as:

$$
L\left(x^{j}\right)=\frac{P(A) p_{A}\left(x^{j}\right)}{P(B) p_{B}\left(x^{j}\right)}=\frac{P(A)}{P(B)} l\left(x^{j}\right) .
$$

The discriminant function in this case has the form:

$$
y=f(x)=x^{\prime} \operatorname{cov}^{-1}(x)\left(m_{A}-m_{B}\right) .
$$

The threshold value of the discriminant function, allowing to make a comparison for decision making about the belonging of an object to a particular class, is calculated on the basis of equation: 


$$
\begin{aligned}
& y_{0}=\frac{1}{2}\left(m_{A}+m_{B}\right)^{\prime} \operatorname{cov}^{-1}(x) \times \\
& \times\left(m_{A}-m_{B}\right)-\ln \frac{P(A)}{P(B)} .
\end{aligned}
$$

Description (7) allows to evaluate the belonging of an object to class $A$ or $B$ using a linear discriminant function with known class probabilities.

\section{Research results}

Fig. 3, 4 show the results of statistical processing of experimental data (Table 1) in the form of histograms and the density distribution of the sulfur content in an alloy obtained from a cupola and an electric arc furnace, respectively. Fig. 5, 6 show the results of statistical processing of experimental data (Table 1) in the form of histograms and the distribution density of phosphorus content in an alloy obtained from a cupola and an electric arc furnace, respectively. It is assumed that the class A corresponds to the data obtained in the process of cupola melting, class B corresponds to the data obtained in the process of electric arc melting.

Fig. 3-6 show that without testing the hypothesis of a normal distribution law, it is not correct to assert that this law is being implemented. Probably there is a systematic error that must be eliminated. However, there is reason to believe that the distribution law corresponds to the normal, based on the known expert experience. Elimination of the systematic error and verification of the relevant hypothesis can confirm this.

Using the algorithm (1)-(7) on the basis of the experimental data given in Table 1, we obtain a classifying rule of the form:

$$
\begin{aligned}
& x^{j} \in A \text { if } \\
& 329.0798 x_{1}-99.9363 x_{2} \geq 22.27076, \\
& x^{j} \in B \text { if } \\
& 329.0798 x_{1}-99.9363 x_{2}<22.27076 .
\end{aligned}
$$

Fig. 7 shows the distribution of experimental points and a dividing line, described by a discriminant function of the form:

$$
329.0798 x_{1}-99.9363 x_{2}=22.27076 \text {. }
$$

The accuracy of the correct classification is determined by the number of correctly classified objects and in this case it is: $P(A)=0.914$, $P(B)=0.971$. This indicates the high quality of the classifying rule, and, despite the seeming deviation of the distribution law of state variables from the normal. To improve the quality of the classification, the range of values of the state variables can be chosen optimally. At the same time, under the optimal one, it should understand the possibility of choosing values of state variables, at which the dispersion matrix of the classes will be equal to each other [18].

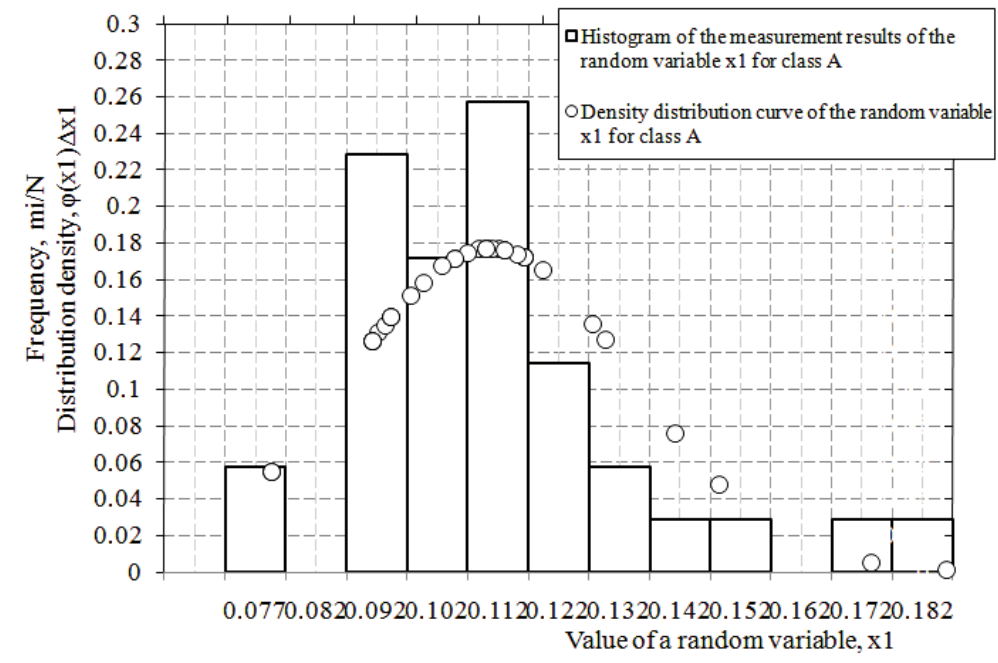

Fig. 3. The distribution histogram of the sulfur content in the alloy obtained from cupola: $x 1=5, \%, \varphi(x 1)$ is the distribution density

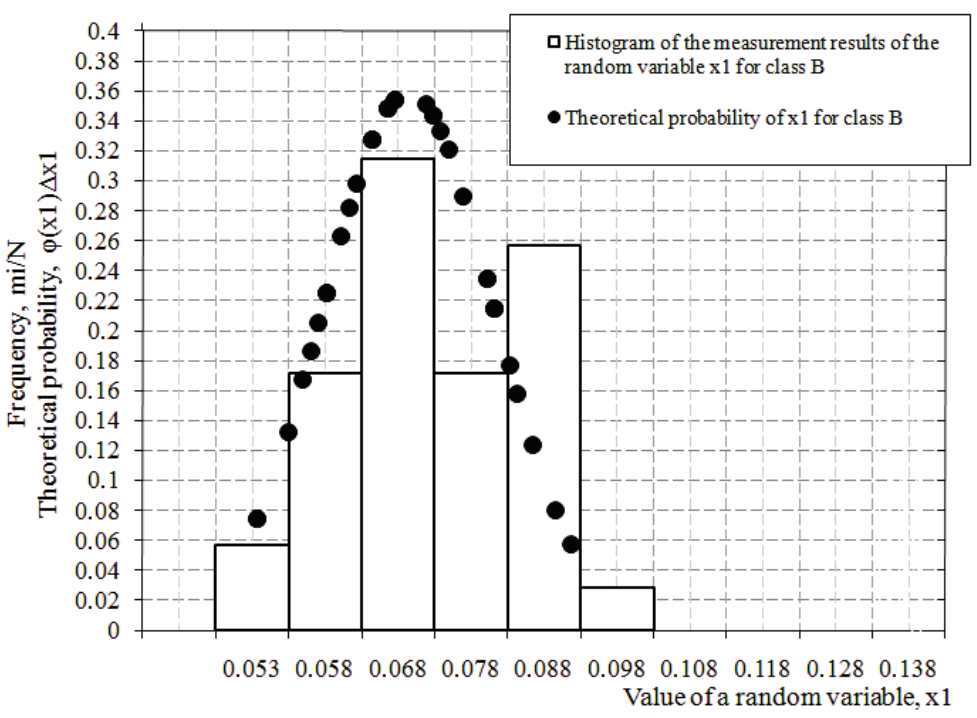

Fig. 4. The distribution histogram of the sulfur content in the alloy obtained from electric arc furnace: $x 1=5, \%, \varphi(x 1)$ is the distribution density

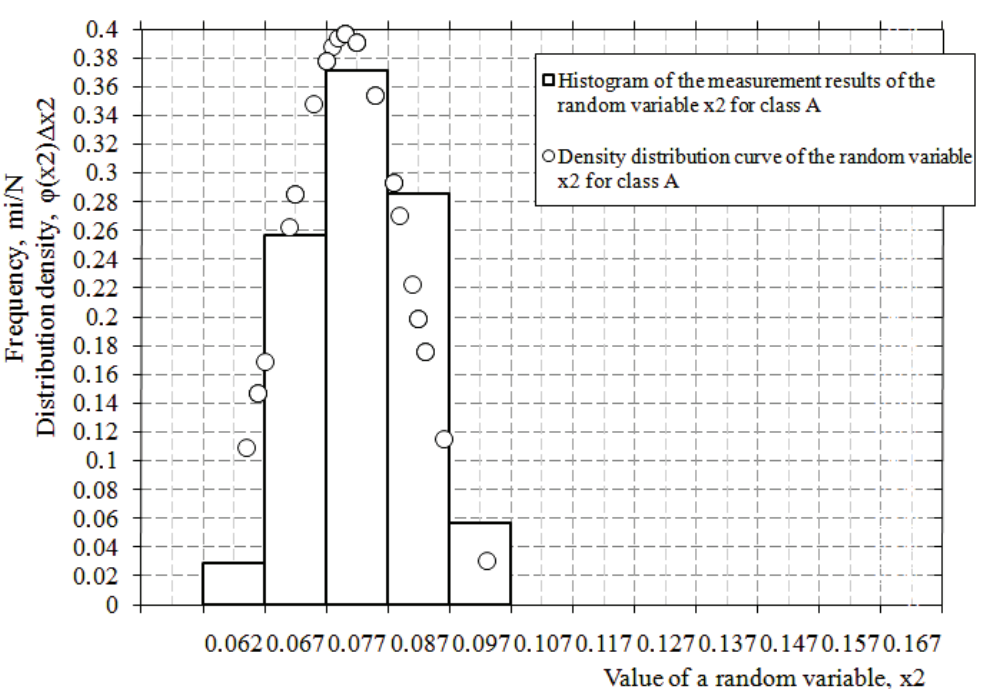

Fig. 5. The distribution histogram of the phosphorus content in the alloy obtained from cupola: $x 2=P, \%, \varphi(x 2)$ is the distribution density 


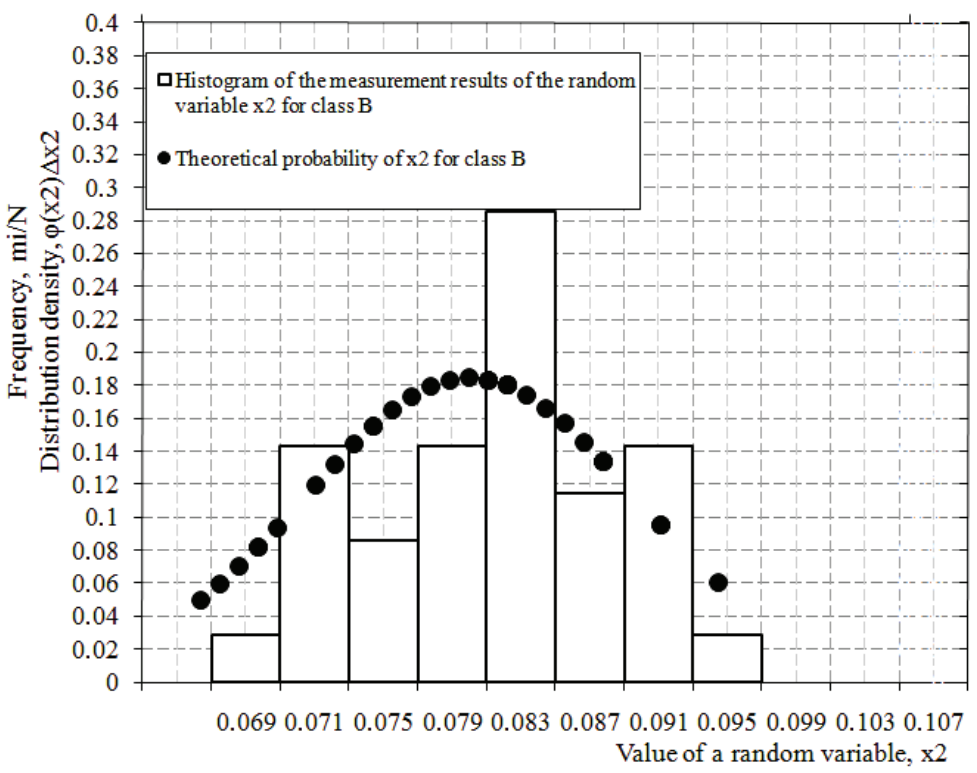

Fig. 6. The distribution histogram of the phosphorus content in the alloy obtained from electric arc furnace: $x 2=P, \%, \varphi(x 2)$ is the distribution density

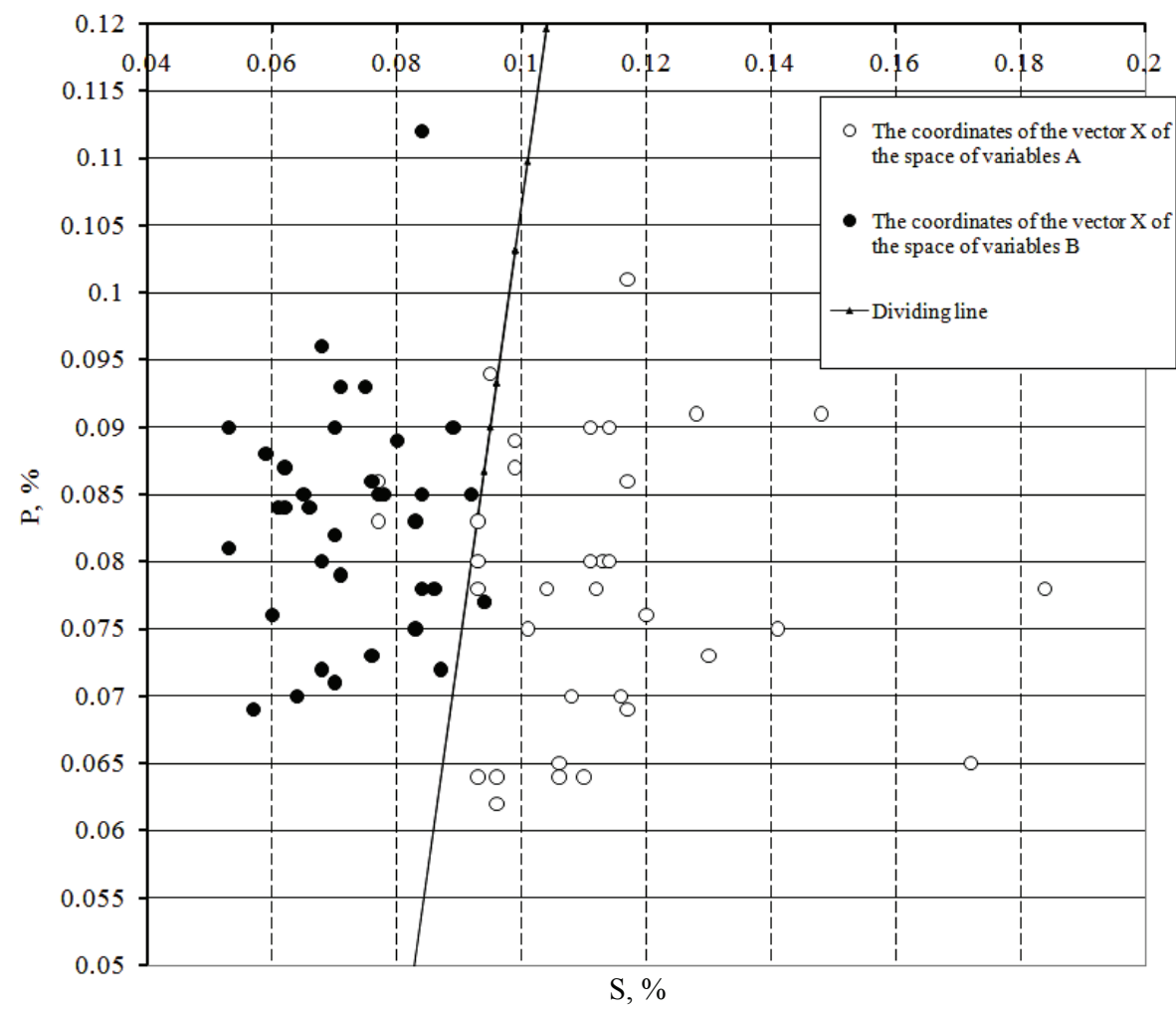

Fig. 7. Distribution of experimental points and a dividing line

\section{SWOT analysis of research results}

Strengths. Among the strengths of this research, it is necessary to note getting a classifying rule with a sufficiently high accuracy. This means that the application of such rule can enable the correct identification of a part of the technological process with a lower parameter of parametric reliability. In turn, this opens the possibility of improving the quality of desulphurization and dephosphorization control due to the correct choice of control actions. As a result, the costs of a substandard finished product - alloy - are minimized.
Weaknesses. The weaknesses of this research are related to the fact that a small sample of data is analyzed, so that the resulting classification accuracy is not exhaustive. With a large sample of data, it is necessary to recalculate the coefficients in the analytic description of the classifying rule, and it may turn out that either the classification accuracy becomes lower or the dividing curve ceases to be direct. A decrease in classification accuracy can lead to an erroneous decision to desulphurization and dephosphorization control and, consequently, to increase the reject of the finished product.

Opportunities. Additional opportunities for using the above results in industrial conditions are associated with the use of the classifying rule in decision support information systems. However, this requires the integration of an appropriate mathematical description in the information control system (ICS), which obviously entails the need for additional investment in the technical support of the melting process.

Threats. The obvious threats when using the results are related to the following circumstance. The use of the resulting classifying rule as the basis for IMS should be proved in terms of comparing the costs of upgrading the equipment or control system and the cost of purchasing ready-made solutions for SCADA systems. If the accuracy of the classifying rule during additional studies for a larger sample of data proves to be insufficient, then the decision to upgrade the existing IMS will be postponed over time. In this case, it is necessary first to obtain a more accurate mathematical description.

\section{Conclusions}

1. On the basis of statistical data processing it is established that an algorithm for parametric methods of pattern recognition can be used to build a classifying rule allowing to identify a part of a technological process with a lower parameter of parametric reliability. It is shown that in this case it is sufficient to build a linear discriminant function.

2. It is shown that the resulting classifying rule provides a high recognition rate $-P(A)=0.914, P(B)=0.971$ for classes $A$ and $B$, respectively. This allows it to be recommended for decision support systems for desulphurization and dephosphorization control in the duplex melting process.

\section{References}

1. Trufanov, I. Scientific bases of the permission of innovative problems identifications in processes automation systems of electrometallurgy of the steel and alloys [Text] / I. Trufanov, 
A. Liutyi, K. Chumakov, I. Andriias, T. Kazanskaia, V. Dzhioev // Eastern-European Journal of Enterprise Technologies. - 2010. № 3/10 (45). - P. 8-23. - Available at: \www/URL: http:// journals.uran.ua/eejet/article/view/2898

2. Razzhivin, A. Informatsionnoe obespechenie sistemy avtomaticheskogo upravleniia dugovoi staleplavil'noi pech'iu po temperature metalla [Text] / A. Razzhivin, I. Sagaida // Visnik SUDU. - 2000. - № 3 (25). - P. 215-220.

3. Demin, D. Mathematical description typification in the problems of synthesis of optimal controller of foundry technological parameters [Text] / D. Demin // Eastern-European Journal of Enterprise Technologies. - 2014. - № 1/4 (67). - P. 43-56. doi:10.15587/1729-4061.2014.21203

4. Trufanov, I. Obshcheteoreticheskie aspekty razrabotki stohasticheskoi sistemy avtomatizirovannoi ekspertnoi otsenki dinamicheskogo kachestva proizvodstvennyh situatsii elektrostaleplavleniia [Text] / I. Trufanov, K. Chumakov, A. Bondarenko // Eastern-European Journal of Enterprise Technologies. - 2005. № $6 / 2$ (18). - P. 52-58.

5. Demin, D. Quality Control at foundries technological aspects in selection of optimal strategies for technical reequipment [Text] D. Demin // Bulletin of NTU «KhPI». Series: New desicions of modern technologies. - 2014. - № 7 (1050). - P. 42-52.

6. Dembovskii, V. Avtomatizatsiia liteinyh protsessov [Text]: Handbook / V. Dembovskii. - Leningrad: Mashinostroenie, 1989. - 264 p.

7. Demin, D. Priniatie reshenii v protsesse upravleniia elektroplavkoi s uchetom faktorov nestabil'nosti tehnologicheskogo protsessa [Text] / D. Demin // Bulletin of NTU «KhPI». Series: New desicions of modern technologies. - 2010. - № 17. P. $67-72$.

8. Vasenko, Yu. Technology for improved wear iron [Text] / Yu. Vasenko // Technology Audit and Production Reserves. 2012. - № 1/1 (3). - P. 17-21. doi:10.15587/2312-8372.2012.4870

9. Demin, D. Identifikatsiia chuguna dlia opredeleniia ratsional'nyh rezhimov legirovaniia [Text] / D. Demin, A. Bozhko, A. Zraichenko, A. Nekrasov // Eastern-European Journal of Enterprise Technologies. - 2006. - № 4/1 (22). - P. 29-32.

10. Ponomarenko, O. Computer modeling of crystallization processes as a reserve of improving the quality of pistons of ICE [Text] / O. Ponomarenko, N. Trenev // Technology Audit and Production Reserves. - 2013. - № 6/2 (14). - P. 36-40. doi:10.15587/ 2312-8372.2013.19529

11. Manikaeva, O. Development of the decision support subsystem in the systems of neural network pattern recognition by statistical information [Text] / O. Manikaeva, E. Arsirii, O. Vasilevskaja // Eastern-European Journal of Enterprise Technologies. - 2015. № $6 / 4$ (78) - P 4-12. doi:10.15587/1729-4061.2015.56429

12. Fraze-Frazenko, A. Algorithm of study neural network for image recognition [Text] / A. Fraze-Frazenko // Technology Audit and Production Reserves. - 2012. - № 4/1 (6). - P. 33-34. doi:10.15587/2312-8372.2012.4781
13. Unglert, K. Principal component analysis vs. self-organizing maps combined with hierarchical clustering for pattern recognition in volcano seismic spectra [Text] / K. Unglert, V. Radić, A. M. Jellinek // Journal of Volcanology and Geothermal Research. - 2016. - Vol. 320. - P. 58-74. doi:10.1016 j.jvolgeores.2016.04.014

14. Fakhar, K. Fuzzy pattern recognition-based approach to biometric score fusion problem [Text] / K. Fakhar, M. el Aroussi, M. N. Saidi, D. Aboutajdine // Fuzzy Sets and Systems. 2016. - Vol. 305. - P. 149-159. doi:10.1016/j.fss.2016.05.005

15. Demin, D. A. Mathematical modeling in the problem of selecting optimal control of obtaining alloys for machine parts in uncertainty conditions [Text] / D. A. Demin // Problems Of Mechanical Engineering. - 2013. - Vol. 16, № 6. - P. 15-23. Available at: \www/URL: http://journals.uran.ua/jme/article/ view/21309

16. Hartmann, K. Statistische Versuchsplanung und-auswertung in der Stoffwirtschaft [Text] / K. Hartmann, E. Lezki, W. Schafer. - Leipzig, 1974. - $552 \mathrm{p}$.

17. Anderson, W. K. Computer-assisted studies of chemical structure and biological function (Stuper, Andrew J.; Brugger, William E.; Jurs, Peter C.) [Text] / W. K. Anderson // Journal of Chemical Education. - 1979. - Vol. 56, № 12. - P. A380. doi:10.1021/ed056pa380.4

18. Aouati, M. Localization of vectors-patterns in the problems of parametric classification with the purpose of increasing its accuracy [Text] / M. Aouati // Eastern-European Journal of Enterprise Technologies. - 2016. - № 4/4 (82). - P. 10-20. doi:10.15587/1729-4061.2016.76171

\section{ПАРАМЕТРИЧЕСКАЯ ИДЕНТИФИКАЦИЯ В ЗАДАЧЕ ОПРЕДЕЛЕНИЯ КАЧЕСТВА ПРОЦЕССОВ ДУСУЛЬФУРАЦИИ И ДЕФОСФОРАЦИИ Fе-С СПЛАВА}

На основе реализации параметрического метода распознавания образов установлена возможность построения классифицирующего правила, позволяющего с высокой точностью провести идентификацию участка дуплекс-процесса плавки «вагранка - электродуговая печь», обладающего более низким показателем параметрической надежности. Это позволяет его рекомендовать для систем поддержки принятия решений по управлению процессами десульфурации и дефосфорации в дуплекс-процессе плавки.

Ключевые слова: параметрические методы распознавания образов, классифицирующее правило, десульфурация, дефосфорация.

Mourad Aouati, Chief Commissioner of Police, Central City Police Department of Constantine, Algeria, ORCID: http://orcid.org/00000003-2744-3592 